The Detection of New Adverse Drug Reactions 


\title{
The Detection of New Adverse Drug Reactions
}

\author{
M.D.B. Stephens \\ with a guest chapter contributed by \\ J.C.C. Talbot \\ and \\ contributions on drug regulations \\ from \\ Dr B. Bons \\ Dr J. Dobbs \\ Dr M. Hadoke \\ Dr M. Kurihara \\ Dr G. Recchia \\ Dr J.C.C. Talbot
}

Second edition

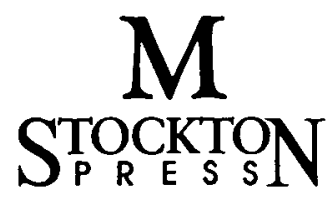


(C) M.D.B. Stephens 1985,1988

Softcover reprint of the hardcover 2nd edition 1988 978-0-333-45417-6

All rights reserved. No reproduction, copy or transmission of this publication may be made without written permission.

No paragraph of this publication may be reproduced, copied or transmitted save with written permission or in accordance with the provisions of the Copyright Act 1956 (as amended), or under the terms of any licence permitting limited copying issued by the Copyright Licensing Agency, 33-4 Alfred Place, London WC1E 7DP.

Any person who does any unauthorised act in relation to this publication may be liable to criminal prosecution and civil claims for damages.

First edition 1985

Reprinted 1986

Second edition 1988

Published by

THE MACMILLAN PRESS LTD

Houndmills, Basingstoke, Hampshire RG21 2XS

and London

Companies and representatives throughout the world

Typeset in 10 pt Century by Medimedia, Godalming, Surrey

British Library Cataloguing in Publication Data

Stephens, M.D.B.

The detection of new adverse drug

reactions.--2nd ed.

1. Drugs-Side effects

I. Title II. Talbot, J.C.C.

615'.704 RM302.5

ISBN 978-1-349-09889-7

ISBN 978-1-349-09887-3 (eBook)

DOI 10.1007/978-1-349-09887-3

Published in the United States and Canada by

Stockton Press

15 East 26th Street, New York, NY 10010

Library of Congress Cataloguing in Publication Data

Stephens, M.D.B., 1930-

The detection of new adverse drug reactions.

Bibliography: $p$.

Includes index.

1. Drugs-Side effects. 2. Drugs-Toxicology.

I. Talbot, J.C.C. II Title.

RM302.5.S74 $1985 \quad 615^{\prime} .7042 \quad 85-2834$

ISBN 978-0-935859-49-2 


\section{Contents}

Foreword vii

Preface to the First Edition viii

Preface to the Second Edition ix

Acknowledgements $x$

1 Introduction 1

2 The Methodology of the Collection of Adverse Event Data in Clinical Trials 28

3 Laboratory Investigations $\quad 51$

4 The Diagnosis of Adverse Medical Events Associated with Drug Treatment 73

5 The Pre-marketing Establishment of the Side-effect Profile of a New Drug 115

6 Post-marketing Surveillance (PMS) 143

7 Drug Rechallenge 201

8 The Ethical Problems of a Pharmaceutical Physician 210

9 The Collection, Storage, Retrieval and Management of Adverse Drug Reaction Data and Adverse Event Data (Guest Contributor: Dr J.C.C. Talbot) 216

10 The Regulations Concerning Adverse Reactions 244

Bibliography 291

Appendix $\quad 297$

Update 327

References 334

Index 361 


\section{Foreword}

We stand on the threshold of what has been called 'the second pharmacological revolution'. During the past three decades major therapeutic advances have been made, but they may well be overshadowed by those of the rest of the century, as new molecular biochemical discoveries, and techniques for genetic engineering, permit control of viral, psychiatric, malignant and autoimmune disease. Tragically, however, this optimistic prediction is threatened by illadvised yet widespread public fear of, and indeed hostility to, new drugs, fostered by a variety of consumer and media lobbies who have not yet understood that a chemical's therapeutic efficacy is inevitably associated with unwanted effects, particularly if used unwisely.

Many books have been written about the design of clinical trials and determination of therapeutic efficacy of drugs, but little has been published on the systematic detection, quantification and evaluation of adverse drug reactions. This process should begin, of course, with the earliest administration of a drug to man, and continue throughout its controlled clinical trials, but is likely only to identify relatively common or bizarre adverse effects. Less common, but nevertheless important, unwanted effects will be recognised only when it is prescribed for larger numbers of patients, usually after it has been marketed, and when its use, therefore, is less closely supervised.

Dr Stephens has been closely involved in the practical problems of adverse drug reaction monitoring for many years, and this book represents an important contribution to the subject which I believe will be of value to all involved in the scientific assessment of drug treatment.

Professor Paul Turner, MD, BSc, FRCP Department of Clinical Pharmacology St Bartholomew's Hospital Medical School London 


\section{Preface to the First Edition}

This book sets out to describe the problems involved in the detection of new adverse drug events both before and after a drug reaches the market and the various methods available to overcome these problems. The methods cover the collection, storage and assessment of the information. It is hoped that it will be found useful to those involved in clinical trials, whether clinical or pharmaceutical scientist. For the latter it is also hoped that he or she will find sufficient information and referenced papers to be able to set up a drug surveillance unit within a pharmaceutical company.

The withdrawal from the market of numerous drugs over the last few years has prompted changes in the regulations in many countries and, therefore, in turn has caused, and will cause, great changes within the pharmaceutical industry.

The most important change will be the realisation that equal effort and money will need to be put into both sides of the cost/benefit ratio in the clinical research of a new drug.

I have resisted the temptation to stray into the more fascinating and controversial areas, such as the law on liability and compensation for drug injury or the history of various established adverse drug reactions, but I hope that the bibliography will have covered these gaps.

All opinions mentioned in this book are my own, unless specifically stated as being otherwise. It should not be presumed that any views or practices described here are those of the Glaxo Group or any of its subsidiary companies, unless stated. 


\section{Preface to Second Edition}

Since the original edition was published in 1985 there have been a number of changes in the field of adverse drug reactions. Important changes in pharmaceutical law in several countries have brought about changes within the industry so that most large pharmaceutical companies now have a department to deal with drug surveillance.

There have been recently several Drug Information Association meetings and workshops dedicated to relevant topics, such as clinical data management, pre-marketing adverse drug experiences, data management procedures, the future of ADR diagnosis: computers, clinical judgement and the logic of uncertainty.

As a result I have rewritten the chapters on assessment of adverse medical events and post-marketing surveillance, and there is a new chapter on laboratory investigations. The chapters on methodology of the collection of adverse event data; the pre-marketing establishment of the side effect profile of a new drug; ethical problems; collection, storage, retrieval and management of $\mathrm{ADR}$ data and regulations have all had extensive changes in order to bring them up to date. The general expansion has resulted in almost double the number of references. In this edition any new information which has arrived after completion of the list of references has been inserted in the relevant chapter with the reference incorporated in the text. Information arriving just prior to going to press has been added after the Appendix. 


\title{
Acknowledgements
}

Whenever there has been need of statistical advice I have run to either D. Robinson or J. Foster at Glaxo Group Research, Ware, and evidence of this is seen in almost every chapter. Dr C. Bulpitt guided my first faltering footsteps in the world of controlled clinical trials and his influence has spread into many aspects of the book. The whole area of form design and post-marketing surveillance results from close collaboration with the late $\mathrm{Dr}$ J. Jackson of Clinical Data Monitoring, Glaxo Group Research, and I am deeply indebted to his help over the years.

I am very grateful to the following for updating the chapter on drug regulations:

United Kingdom
United States of America
France
Germany
Italy
Japan

\author{
Dr J.C.C. Talbot \\ Dr J. Dobbs \\ Dr B. Bons \\ Dr M. Hadoke \\ Dr G. Recchia \\ Dr H. Kurihara
}

I am also very indebted to my colleagues: $\mathrm{Dr}$ J. Talbot for his chapter on handling data, Ms M. Woods for indexing, Mrs B. Long for proofreading and Dr P. Meyer-Franzen.

It is also a pleasure to thank:

1. Dr Emmanueli of Farmitalia Carlo Erba for permission to publish his revised algorithm (August 1983).

2. Dr Ruskin for his two algorithms on drug-event association and drug-death association.

3. Dr J.A. Lewis of ICI and Elsevier Biomedical Press for permission to reproduce his statistical tables on the numbers of patients required for PMS.

4. Drs S.N. Ciccolunghi, P.D. Fowler and M. Chaudri for the use of the 'Ciccolunghi-Fowler-Chaudri Method'. 
5. Dr B.D. Dinman and JAMA for permission to reproduce his tables of risk 'The reality and acceptance of risk', JAMA, 1980, 244(11), pp. 1226-1228. Copyright 1980, American Medical Association.

6. Dr C.J. Stevenson for help with the design of the skin ADR form.

7. Dr J. Haller, Dr J. Ward and Dr R. Amrein and the editors for permission to reproduce the table on page 136 from Drugs and Driving, J.F. O'Hanlon and J.J. de Gier (Eds), and also the Publishers Taylor and Francis Ltd.

8. Dr J. Levine for the details of SAFTEE.

9. Prof. D.L. Sackett, Dr R.B. Haynes and Dr P. Tugwell and the publishers Little, Brown \& Co. for permission to reproduce the tables on pages 111-113 from Clinical Epidemiology, a basic science for clinical medicine. Copyright 1985.

10. Prof. D.M. Davies and the Oxford Press for permission to reproduce most of chapter 4, which was originally published in Adverse Drug Reactions and Acute Poisoning Review, 1987, 1, 1-35.

11. Dr G. Venning and Prof. D.M. Davies for permission to reproduce the graph on page 125 which originally appeared in Adverse Drug Reactions and Acute Poisoning Review, 1984, 3, 113-21.

12. Dr J.A. Tangrea for the details of the basal cell carcinoma prevention trial.

13. Dr N. Mohberg for details of the forms used in clinical trials for medical events.

14. Glaxo Group Research Ltd for permission to reproduce various forms.

15. Dr W.H.W. Inman for information concerning P.E.M.

16. Dr W. Castle for information concerning the C.I.O.M.S. form for ADR reporting.

17. The post-marketing surveillance working group of The International Federation of Pharmaceutical Manufacturer's Association (IFPMA) for the definitions of terms from an IFPMA position paper.

18. PJB Publications Ltd for permission to reproduce extracts from Eurodrugs Step by Step. 